\title{
The Social - Political Significance of Ruwatan Desa Ritual
}

\author{
Hidayatul Wahidah \\ CRCS - UGM Yogyakarta \\ hidayatulwahidah@gmail.com \\ Akhmad Jazuli Afandi \\ UIN Sunan Ampel - Surabaya \\ jazz_ull@yahoo.com
}

\begin{abstract}
The Punden of Mbah Sentono is a sacred landscape that is used frequently by people to increase their spirituality. It is recognized as a sacred place to perform rituals such as tahlilan, slametan and ruwatan desa. The main issue I raise in this paper concerns the social-political significance of the rituals. The three main questions are, first, how is ruwatan practiced in the Punden of Mbah Sentono? Second, how have political actors used the ritual in the punden as a political tool in an election? The last, how have people also used the ritual in the punden to counter the political actors' use the ritual? I will show that the rituals do have social-political significance and argue that both political actors and people in society have mutual relations through the rituals. From this point of view, I state that ritual in the Punden of Mbah Sentono is divided into two time periods, "during election period" and "after election period". "The ritual during election period" are tahlilan and slametan which are handled by the candidates of the local election to build political support, whereas "the ritual after election" is ruwatan desa which is also used by the winner for negotiation and reconciliation to ease the negative impacts of the competitions during the local election, which affect people. On the other hand, people also use the rituals to ask for financial support from the candidates for holding big ruwatan desa and kirap. In the years before and after the election, ruwatan desa is held as small events. In this research, I analyze the social-political significance of ritual, using a theoretical framework informed by Kertzer.
\end{abstract}


[Punden Mbah Sentono adalah tempat sakral yang sering digunakan sebagai tempat spiritual oleh orang-orang untuk meningkatkan spiritualitas mereka. Punden tersebut diakui sebagai tempat sacral untuk melakukan tahlilan, slametan dan ruwatan desa. Isu utama yang saya angkat didalam tesis ini adalah siknifikansi social-politik pada ritual. Ada tiga pertanyaan utama; yakni, pertama, bagaimana ruwatan desa ritual dipraktekkan di punden Mbah Sentono? kedua, bagaimana actor politik menggunakan ritual didalam punden sebagai alat politik didalam pemilihan? Terakhir, bagaimana masyarakat menggunakan ritual di punden untuk keluar dari actor politik? Saya akan menunjukkan bahwa ritual mempunyai siknifikansi social-politik dan beranggapan bahwa actor politik dan masyarakat mempunyai hubungan timbal balik melalui ritual.]

Keywords: punden, ruwatan, slametan, political leader,

\section{Introduction}

Pilgrimage to punden or other sacred graves categorized as spiritual landscape could be considered a tradition which is still practiced by many Javanese people up to now. Conceptually speaking, the spiritual landscape might appear in form of the sacred or the profane. Indeed, the sacredness of something differs from region to others regarding the culture and history. Allerton argues that "the concept of spiritual landscape is meant as the attention of the people to imagine the spirit to emerge from or to be connected to places, and to the attitudes that may have to the "hidden" or mysterious realm beyond within the visible earth".

Pilgrimage is not only worldly activities related to journey, tourism, traveling, or others, but it is also connected to a form of contestation among travelers in searching spiritual meaning in sacred rituals, holy places, and other sacred things. Bagus Laksana asserts that "pilgrimage" is also an extremely rich and complex practice where a deeply religious and spiritual search for God and self exists alongside the more mundane need for the therapeutic effects of travels and tourism, and where a strictly pious activity for obtaining God's blessing intersect with complex framework of cultural or ethnic identity formation." Thus, pilgrimage is a kind of religious practice to the spiritual landscape

${ }^{1}$ Chaterine Allerton, "Introduction: Spiritual Landscapes of Southeast Asia, 235251,” Anthropological Forum, Vol. 19, No. 3 (Nov., 2009). Routledge. 235. 
for asking the blessing from God. Pilgrimage also is a continued practice that is done at a certain time. People believe that there are some sacred times that can be a good time for doing the pilgrimage to the spiritual landscape.

In this case, in Segunung, people do ruwatan desa ritual. This ritual is kind of rejecting disasters or calamities that will come to the village. Conceptually speaking, the purpose of this ritual is to protect the village from Batara Kala who will eat people or village that get Sukerta. This ritual is held by some people in Mojokerto once a year in Ruwab month. As the primary case, this paper focuses on ruwatan desa ritual in 2014 and 2015 - as the comparison in general-, because of some reasons.

Ruwatan desa ritual in 2014 was categorized as special ruwatan desa ritual in Segunung because it was held after head village election that has a negative impact for social relation of people because the process of this ritual was prepared by some people in that village that can be a good way for reconciliation and negotiation way. Local election in Segunung often creates conflict among people because of the different political background of a candidate election. So, the ruwatan desa ritual in 2014 is quite helpful for negotiation way and reconciliation, because people came to that punden and brought some tumpeng(s), incents, offering that was eaten together in that place, and then continued with the other entertainment. There was performance of wayang or puppet in the afternoon, then big parade or kirap, and the second wayang is held in the night. Thus, the process of that ritual is a full day activity. They prepare and do it together.

The second reason is that ruwatan desa ritual in 2014 was held in big ritual with big kirap that need much money. It was different with regularly ruwatan desa ritual. As the comparison, in previous and 2015 ruwatan desa ritual, ruwatan desa ritual was held only in small ritual without big kirap. Moreover, in 2015, the ruwatan desa ritual was held only bancakan or slametan in the punden and pengajian in bale desa (Lit. village hall). It is a really simple ritual. Interestingly, where did people get much money for holding big ruwatan desa ritual with big kirap? What is actually the purpose of holding a big ritual? Those questions become the second background of this paper.

The interesting thing that can be taken as the important point is, the punden of Mbah Sentono has the fascination that can gather people in a special space that is ruwatan desa ritual. This space as a spiritual landscape is not the only place for increasing the spirituality of the people but also can be a good place for social interaction between one 
and other people. So, this good tradition in Segunung can be practiced by the political leader for their personal interest before and after the election.

This practice shows that a different background is not the threat of diversity, and it can be a good way to unite people. There are many problems in another place that those cases become the obstacle for doing blaming. As we know that in Islam, pilgrimage to the grave is being discussed commonly. It is considered as primitive of shirk (idolatry), because it is not clearly mentioned in Alquran. Let us see the cases in Kediri, Eva Amalia states that in 2001, there is an accident, the Muhammadiyah would have dug the grave, and because they think that that grave is the symbol of mushrik (idolater). ${ }^{2}$ So, it can be a good way of negotiating between some different backgrounds in society. Yet, usually in some places, it becomes a crucial problem. And also, in that village, because there is an election for the chief of the village, people usually are disparate because of the fanatic in their political background which is different. But in this phenomenon, this ritual is held in good cooperation among the different background of people. People will help each other for preparing ruwatan desa ritual after an election in Segunung and other events that can be the way of negotiation for reconciliation. Moreover, it can be a meeting point among some ethnicity, organizations, political backgrounds, and religions. People will share and help each other for preparing the ritual or usually, they meet in that punden when they have some hope.

This phenomenon can be a miniature of Indonesia country more broadly. As it is well known, that Indonesia has many ethnic groups, organizations, political backgrounds and number of religions. These identities may be expressed or manifested in elections. This may create problems and conflicts after the election; it may also be a window for blaming shirk (idolatry). Especially in Indonesia, which is a democracy. It can create polarizations and frictions. So, the pilgrimage to the punden can be the meeting point and ritual can be an example for making negotiating space and harmony. This picture forms the backdrop of this research. The objective of this paper is to provide more knowledge about ruwatan desa ritual, how ritual enters into the political realm, and the social-political significance of ritual during and after the 2013 local election in Segunung.

${ }^{2}$ Eva Ida Amaliyah, Makna Ritual dan Bersih Desa serta Respon di Kalangan Masyarakat Desa Sekoto Kecamatan Pare Kabupaten Kediri (Gadjah Mada University: Center for Religious and Cross-cultural Studies, 2007), 98. 


\section{Slametan}

There are many types of research that have already talked about spiritual landscape and slametan. Here, I consider ruwatan desa ritual as an example of slametan. I offer journal from Catherine Allerton, Introduction: Spiritual Landscapes of Southeast Asia, The Journal of Anthropological Forum. Vol. 19, No. 3, November 2009, 235-251. In this journal states that spiritual landscape in South East Asia has been affected by new religious forms, migration, changing cultural practice and political project; yet, this journal also explains about the debatable issue by offering some statements from some scholars about the spiritual landscape. Allerton argues that,

"LLandscape', as a concept in the human sciences, tends to be utilized in one of three distinct ways. Firstly, it may be used in the common, everyday sense of a 'natural' or physical environment, a taken-for-granted backdrop of hills, rivers, and valleys. This is how landscapes are referred to in most ethnography. Secondly, 'landscape' may be used to refer to a distinct 'way of seeing', a representation, as in 'landscape painting'. Thirdly, 'landscape' may be utilized to refer neither to a 'natural' object nor to a cultural 'representation', but to a historical process of interaction between people and the environment in which both are shaped (Allerton, 2009: 236). In addition, Allerton adds Many mid- to late-twentieth century accounts of Southeast Asian societies, particularly historical accounts of the region's Indic states, stress the significance of what is frequently labeled 'sacred geography', or 'a conceptual system in which certain places are of central ritual importance because it is there that one accesses cosmic currents of ritual purity and power'."3

In book “Java, Indonesia and Islam”. Mark Woodward's explains the interpretation of Slametan and three principal components of it in Indonesia. He argues that the slametan is a locally defined Muslim rite. He criticizes the Clifford Geertz's argument about Slametan that is misleading. According to Woodward, “Geertz's criteria that distinguish Islam from animism are misleading; the slametan is an example of a ritual context that links blessing and food and extends from Arabia to Southeast Asia." "Woodward shows the debatable between his interpretation and Geertz's interpretation. One of his focusing is on three principles of ruwatan generally. It is different from my paper on holding slametan in a particularly sacred place; there is a lack component because places can be determined as a principal component. Most

\footnotetext{
3 Allerton, Introduction, 236.

${ }^{4}$ Mark R Woodward, Java, Indonesia and Islam (New York: Springer, 2011), 113.
} 
people there will hold the slametan in a sacred place that is considered a spiritual landscape.

Andre Moller, Ramadan in Java: The Joy and Jibad of Ritual Fasting. ${ }^{5} \mathrm{He}$ explains about visiting the grave and how the debatable of ruwahan that is related to slametan. He also mentions some scholars defining the slametan. He explains clearly about it, "This 'undramatic, almost furtive, little ritual' has caused debate among scholars of Islam in Jawa." ${ }^{\prime \prime}$ In his book, he also explains the definition of slametan and its debatable understanding among scholars, but he does not mention the sacred ultimate reality in that case. Also, he does not explain slametan as negotiating event. It is different from this paper.

Eva Ida Amaliyah in her book "Makna Ritual dan Bersih Desa Serta Respon di Kalangan Masyarakat Desa Sekoto Kecamatan Pare Kabupaten Kediri" explains the meaning of ritual "bersib desa" and how the response of "bersib desa" from many sides. ${ }^{7}$ In that thesis, she already shows the debatable of ritual bersib desa as shirk. According to her, "in 2001, there is an accident, the Mubammadiyah would have dug the grave, and because they think that that grave is the symbol of mushrik." ${ }^{8}$ Basically, there is another interesting thing that found here. Besides the interesting meaning of that ritual, we found that the sacred cemetery in that place become central of people asking what they want. The people are from various religions, organizations, traditions, and local belief. So it is an interesting thing that I do not find in this thesis and I can see the inter-religious dialog between one religious people to the other religious people.

Lies Mariany, Ruwatan di Taman Mini Indonesia Indah: Kajian Dinamika Ruwatan Murwakala, proceeding the $4^{\text {th }}$ international conference on Indonesia Studies: "Unity, Diversity, and Future", (FIBUniversitas Indonesia). Pp.1016-1040. Lies discusses Ruwatan Murvakala that is held in Jakarta, especially in TMII and sees how the process of ritual "Ruwatan Murwakala" held in TMII Jakarta to be followed by multi-ethnic people of Jakarta. According to her, "this ritual focuses on Ruwatan Murwakala that is related to cultural context and more focuses on the difference from this ritual in TMII and Ruwatan Murwakala ritual in the origin culture". This paper talks the

\footnotetext{
5 Andre Moller, Ramadan in Java: The Joy and Jihad of Ritual Fasting, (Sweden: Lund University, 2007), 266-281.

${ }^{6}$ Ibid., 270

7 Amaliyah, Makna Ritual, 15.

8 Ibid., 98.
} 
same thing with this paper on ruwatan ritual, but this paper talks about the significance of social-politic from ruwatan desa ritual.

Generally, those researches can be the starting point of this research, but this paper is more focusing on the significance of socialpolitic from ruwatan desa ritual. So, this ritual can be the way to minimalize the conflict that is caused by democracy in that village and negotiating a place for people, the way strengthening their identity and the way of punden become intersection or meeting point of the people.

\section{Theoretical Framework}

Spiritual landscape in Mojokerto is very important for the people because they think that the spiritual landscape can link them to their ancestors and God. Therefore, the aim of the case study in this research is to understand the existence of punden as a spiritual landscape that is used as the important element in holding ruwatan desa ritual in Dlanggu Mojokerto and the social-political significance of ruwatan desa ritual in punden of mbah Sentono. According to Allerton, "People may engage with spiritual landscapes in ritual activities, but also in a more pragmatic fashion in the course of everyday life." So, the existence of punden as the negotiating and gathering place is not only for strengthening their spirituality but is also can be interaction place for sharing and helping each other in their daily life. Moreover, it can be a good way for reconciliation after the local election.

Following the concept hierophant by Eliade. Eliade tried to define and divide the sacred and profane. Sacred or hallowed it something real, but that real thing can be a media for the spirit of their ancestors to dwell in the landscape. Like mountains, trees, rocks and so on, they have the power to connect people with things beyond human ability. In this research uses the punden as the object of ruwatan desa ritual in Dlanggu Mojokerto. People do not worship the punden, but they try to connect and deliver their hope with the ancestor that is dwelling in that place. This phenomenon is called as bierophant. According to Eliade, hierophant is a manifestation of the sacred in the real world.

On the one hand, related to the social-political significance of ritual in Segunung, I Follow Kertzer's concept who relates ritual to political power. The social-political significance of ritual means that is importance interest of the ritual related to the social and political interaction in the village. He argues that there is some importance of

${ }^{9}$ Allerton, Introduction, 238. 
ritual; constructing political organizations, creating political legitimacy and solidarity, and for limiting or reducing conflict. ${ }^{10}$ Constructing political organization is that as according to Kertzer, "This use of ritual to tie local communities to the center of state power also assumes urgency when new national establish." ${ }^{11}$ The ritual can build the political organization to handle people. Building political organization here is including building political supporters in election or in other word it can be called as looking for the supporters. For him, "The metaphor of a journey guides the entire enterprise: campaign as pilgrimage. The population is supposed to get to "know" the candidate through his highly ritualized appearances, while the candidate uses the rites to present a certain image of him and to contrast this with the image he creates of his competitors." $" 12$

The second importance of ritual is creating political legitimacy and solidarity. According to Kertzer, "New political systems borrow legitimacy from the old by nurturing the old ritual forms, redirected to a new purpose." ${ }^{13}$ On the other hand, quoting from Kertzer's statement, he pointed in his research that "In rendering their political system sacred through the use of ritual, people also end up legitimizing the power held by political leaders." ${ }^{14}$ So, ritual creates solidarity of people in the same place, time with different people and the background of the people that is possible to make and strengthen the solidarity of the people.

The last importance of ritual is for limiting or reducing conflict. Ritual is held in public space and joined by some people in the same place and time. This togetherness can be a good way of limiting or reducing conflict in society because ritual is prepared by all people and help each other.

\section{The Local Election of Segunung}

Beside PILKADA/Pemiliban Daerah (Provincial Election) or PILPRES/Pemilihan Presiden (Presidential Election), local election or PILKADES/Pemiliban Kepala Desa is also an interesting process of democracy. It is held with a direct system election by people in society. As according to Zuhro who conducts research in Tulungagung East

\footnotetext{
${ }^{10}$ David L Kertzer, Ritual, Politic, and Power (London: Yale university press, 1988) 1314

${ }^{11}$ Ibid., 23.

12 Ibid., 108.

13 Ibid., 42.

${ }^{14}$ Ibid., 38.
} 
Java that the tradition of direct system election to choose the head or leader in Java Island is developed since a long time ago. ${ }^{15}$ Yet, according to village head of Segunung, ${ }^{16}$ people in Segunung is aware that direct system election is kind of heritance from ancestral.

Zuhro also adds statement from Ibnu, according to Ibnu Tri Cahyo, the lecture of law in Brawijaya University, Malang, Indonesia, who are involved on making RUU of village government/ administration, argues that in 2007 in East Java as sampling, the head village election is held serentak (in same month) in all villages for some reasons. The first reason is for avoiding botoh (gambling). Gambling can destroy the democracy system because botoh players (gambler) do many strategies for their jagoan (candidate of lurah for their gambling); moreover, they use bad strategy to reach it. For examples, they can buy vote, fool their rival, coercive the voter for choosing a candidate who are their jagoan (candidate of gambling) and bribe the committee of election. So, the botoh players spend much money than the candidates do. The second reason is to increase the participation of people for doing democracy. In many cases, people have high participation for doing PILKADES if compared with PILKADA and PILPRES. It can be seen in case of Segunung that will be discussed below.

Let us turn in the local election in Segunung. Segunung can be categorized as high competition for some candidates and cocok (supporter's actor) and the impact was going on for several months. Because they used all kind of strategies to get supporters, they sometimes use money politic strategy to reach it. Yet the tradition of gambling existed too. It can create conflict between supporters and can create line among people in society. So, from those phenomena, the rite and ritual in the punden of Mbah Sentono was commonly used as fascination and intersection among people, because people can gather in same place and event while share together.

PILKADES in Segunung was held in late of 2013. There were 3 candidates of lurah (head village election) which were Titik Indrawati, Sumadi Siswoutomo and Sumei. Titik Indrawati was incumbent of village head before. She was the only woman who becomes lurab in this village. Her education was from SMA (Lit. senior high school). Sumadi Siswoutomo was pensioner from PNS / Pegawai Negeri Sipil (government employees). He was the only candidate who has bachelor education.

\footnotetext{
15 Ibid., 58.

${ }^{16}$ Sumadi Siswo Utomo, the Chief of Village on Segunung, Interview, January 24, 2015.
} 
The last candidate was Sumei. His education was from SMA (Senior High School). From those three candidates, Sumadi had the highest education. So, this occasion can be used by Sumadi as his confident.

Basically, high education was not priority for registration in election. Since people had education from senior high school can register. The important thing was that they have much money, because it needed more than hundred million rupiah. Basically, as according to Muslimin, there were some people who are more potential to be lurah based on their ability, but they did not, because they had no much money to register as candidate of lurah. To know how much money in election, before election people established committee of election with all candidates. The committee of election included BPD/Badan Permusyawaratan Desa (Village Consultative Agency), LPM/Lembaga Pemberdayaan Masyarakat, village civil servant, and Tokoh Masyarakat (the Elders). They decided that cost of election needed 90 million rupiah; it was responsibility of all candidates. So, each candidate had to pay 30 million rupiah. Then all candidates discussed and decided to give uang sangu (money to the vote) 40.000 rupiah each person after giving vote. As according to committee of election, Muslimin argued that uang sangu replaced their salary in the day because they preferred to participate in local election than to work. ${ }^{17}$

As it is mentioned before, the candidates needed much money not only for the cost of registration in an election but also the cost of campaign and preparation. Six months before an election, all candidates did campaign and lobbied the important figure in Segunung such as getting closer with the juru kunci of the Punden of Mbah Sentono (People who handling the punden), because the punden of Mbah Sentono is an important landscape that can unite people in Segunung. From all candidates, each candidate had their own characteristics. Those three candidates did competition and used many strategies. Titik Indrawati was known as her extravagant with her money. As according to Hasan, He argued that, she contributed her money to all formal school such as SD, MI, SMP, and SMA or informal education school as like as pesantren and TPQ. ${ }^{18}$ Sumadi was known as his pilgrimage tradition in sacred place and blusukan. He did the pilgrimage to the punden of Mbah Sentono and other punden in Segunung village. The term "blusukan" also means gathering and sharing with people in many kinds of occasions. He usually takes place in the coffee shop, sawah (rice

${ }_{17}$ Muslimin, the people of Sumberingin Village, Interview, May 2, 2015.

${ }^{18}$ Hasan, the people of Ssegunung, interview, January 25, 2015 
field), and in other common places for people in society. And Sumei was known as his fear spending his money. His supporters were commonly from his family line.

As tradition is this village, there was an open house tradition and permitted tradition for the candidate of lurah. An open house was held in each candidate of lurab's house and permitted tradition was permitting to the punden. The permitted tradition was the obligation for every candidate of lurah in Segunung as according to Suwardi and Kartono. ${ }^{19}$

A month before, Titik Indrawati and Sumadi Siswoutomo held some agenda with terop (awning) in their house. It was such kind of open house to welcome and serve people, especially for the cocok and supporters, whereas Sumei only held an open house in his house without terop. Muslimin explained that open house almost needs 500 million rupiahs, because the whole day in a month, people were served cigarettes, snack, and food. ${ }^{20}$

On the other hand, as mentioned before, in Segunung there was a pilgrimage and permitted tradition for a candidate of lurab to both punden of mbah Sentono and the grave of mbah lurah. Punden of $m b a b$ Sentono is already explained before which is grave of the clearing village person. The punden of mbab Sentono has deep meaning for people there. It becomes a spiritual landscape in their daily lives. Yet mbah Lurah is the first village head in Segunung. Conceptually speaking, as according to Suwardi, all of the candidates always came to the grave of mbah lurah and waited for a white tiger of mbah lurah. It symbolized that his permission was accepted by mbah lurab. ${ }^{21}$ As an illustration, the guest was accepted by the house owner. So, the owner has welcomed the guest. This can guarantee that the candidate will be the winner.

Besides holding an open house in their home, all candidates created tim sukses before the election. In other word, tim sukses can be called as cocok (supporter's actor). Each candidate always had several tim sukses or cocok in every hamlet. The duties of tim sukses were, they explained the vision and mission of their candidate to people in society. They persuaded people to choose one of the candidates as according to their jagoan. Money politic was commonly used in this stage. The candidate gave money to their tim sukses or cocok. Then, the tim sukses or

\footnotetext{
${ }^{19}$ Suwardi, the people of Segunung, interview, February 01, 2015.

${ }^{20}$ Muslimin, the people of Sumberingin, Interview, May 2, 2015)

${ }^{21}$ Suwardi, the people of Segunung, Interview, February 01, 2015).
} 
cocok gave every people as according to their zone. A tim sukses or cocok had zone consist of at least 50 people in a hamlet.

Beside competition among candidates, there was kind of competition among tim sukses or cocok too. They came door to door to give money in every house before the election. The nominal of money was according to the decision of each candidate. Sumadi and Titik gave 50.000 rupiahs for every person, And Sumei gave 30.000 rupiahs. The tim sukeses usually also joined in some Islamic events, such as pengajian, tablilan and some events in REMAS activities.

The important thing was that all candidates competed for holding rite or tablilan in punden of mbah Sentono because it has the fascination for people in Segunung, and it became media for looking for supporter and showing the existence of the candidate. In this case, before the election, the punden of mbah Sentono was under controlled by Sumadi; Sumadi had dominant power because he had given some to renovate the punden. Sumadi held tablilan in the punden of mbab Sentono. He invited all the people who wanted to join this tablilan. At the end of tablilan, he explained about her vision and mission to people. In this phenomenon, I argue that the punden of mbab Sentono can be good media for a candidate to look for people to vote. On the other hand, people used this opportunity as a good occasion. Because the punden as their sacred place for their spiritual landscape in their life, people always want their punden to be renovated. In this turn, people often ask some contributions from the candidate of lurah to renovate the punden. It showed that there was the social-political significance of punden which plays a role.

A day before the election was a silent day (hari tenang). Hari tenang was free from the campaign. All candidates were forbidden to go anywhere and each cocok also were forbidden to do the campaign in the door to door. This day was for preparation day for all candidates. Interestingly, in this day, the botoh was quite busy. Sometimes they did not sleep because they waited for pulung in each candidate's house. Pulung is kind of fire circle like the moon. As according to Geertz,

"He said that there was a kind of "spiritual stuff" called a pulung which, visible and shaped like a moon, descend on the chosen candidate for village chief. Only village chiefs and the king of the entire country have pulungs (letter's being much larger), which shows that the position of a lurah is more important than that of bupati or wedono (head of regency and a district, 
respectively). When one lurah dies or goes out of office, his pulung leaves him and searches for a new lurah. (It sometimes momentarily goes village is in danger.) The candidates often sit in the office when something special is up or the pulung hovers over them choosing the one that is most pure. Lurah candidates sometimes give a slametan at the danjang's grave in order to attract the pulung. There is one pulung for every village. It stays with the lurah until he dies or no longer acts nobly. In the latter case, it leaves him, his village becomes sick, famished, and disorderly; people will no longer obey the chief. Soon he is forced to resign, and the man to whom the pulung has gone to go to the king, and he said he thought it had gone to Djakarta and Bung Karno (the president of the Republic) had the king's pulung now."22

As it is known that Geertz conducted his research in 1960, people believe in pulung as the symbol for the chief or lurah. Interestingly, in this era, local election follows democracy through direct system election, but the idea of pulung is still believed in Segunung as the message from the ancestor.

In the day of the election, it was quite busy, crowded and noisy. People called it as "dunve gawe gede-gedean". It meant that the village had a really big event. All women were quite happy because, on the day of the election, there were so many bom-boman from each cocok of a candidate. They got 100.000 rupiahs from each cocok. Bom-boman was additional money and in the different term, it is money politic. This bom-bom also happened in other places like in Tulungagung indifferent thing. In Tulungagung, bom-boman was given with nasi bungkusan, whereas In Segunung, the target of bom-boman was women when they were in bakul in the morning. Bakul was the person who sells vegetables, meat, fish and all kind housewive's needs. The Bakul said that in the day of the election, she sold many kilos of meat which was very expensive and it was sold all. ${ }^{23}$ At the same time, in the village hall, it was also quite noisy. There were so many people who sold many kinds of food, snack, accessories, toys, and others. Moreover, there were many played zones for kids, because people who give a vote, they were with their kids; and it was possible the kids want to play the game. It really looked like a big market in a day.

${ }^{22}$ Clifford Geertz, The Religion of Java (Chicago: The Chicago university press, 1960), 26.

${ }^{23}$ Sumaiyah, the people of Segunung, Interview, May 2, 2015. 
Inside village hall (bale desa), all candidates came to bale desa (village hall) and sat in front of people in kuade. Kuade is wedding decoration in Java. It consisted of Javanese style decoration with Javanese costume. All the candidates wear wedding costume. Titik wears kebaya, and both Sumadi and Sumei wear kebaya for men. So, all candidates were called as kemanten. They were like the bride and groom with Javanese costume.

The plebiscite started at 07.00 until $14.00 \mathrm{WIB}$ (Indonesia Bagian Barat/West Indonesia Time Zone); then polling count was until 17.00 WIB. People gave vote quite enthusiastically. Almost all people gave their vote. After giving vote then putting it in the ballot box, people got money 40.000 rupiahs, and then they will buy something interesting outside the village hall. On the one hand, there were many botoh waits the pooling count outside the village hall. According to Muslimin as one of the committees in an election, in the late process of polling count, he said that there was a conflict between the botob in outside. It was quite noisy until disturbed polling count. But this conflict can be handled, the security of election drives out them from village hall area.

The local election result showed how a candidate's strategy has worked. The number of the voter was $2421 .{ }^{24}$ Most of the people participated in this local election which can be seen from the number of voters who are not participating election only 5 people. The result was Sumadi Siswoutomo and Titik Indrawati got slightly a number of votes, Titik Indrawati got 1004 and Sumadi Siswoutomo got 1279, whereas Sumei only got 79. It already showed that people in Segunung was quite pragmatic people. The candidate, who gave the higher money and can use the punden of Mbah Sentono as their tool for the campaign, will get many supporters such like Sumadi who really used the punden as an important media for his campaign. So, he became the winner of an election.

Finishing election did not mean finishing everything related to a local election. After the election, there was a new situation. It felt kind of cold situation. The impact of an election was felt in several months. There was a conflict between tim sukses, but it did not bring violently. There was a line between supporters to other supporters. In other words, the village had at least two groups or clusters of people; the Titik and Sumadi's group, because summer's supporters did not really exist.

Before the election, the relation among people was good. Every morning before going to the rice field, they usually go to the coffee

${ }^{24}$ Muslimin, people of Sumberingin, Interview, May 2, 2015. 
shop just a moment together without any line between them; or in the afternoon, before they went to their home, they would share in the rice field together or in a coffee shop again. But the situation changed after the election. They did not share together in the same coffee shop and they did not say greeting if passing by in the street. This was the negative impact of a local election that is still happened in several months.

On the one hand, there was an impact on the loser of the election. Titik Indrawati as the previous incumbent of lurah was lost in this turn. People never saw her after the election. Her house was always quiet, closed; and it looked like there were no people inside. According to Hestin, Titik left her house and moved to her son's house in Jakarta. ${ }^{25}$ Whereas Sumei, Sumei and his family never did interaction with people. Moreover, he usually joined Istighosah in Pesantren before, now, he did not join it. His son did not join reciting Alquran (TPQ) in pesantren again. So, those phenomena show that there was also a negative impact on the loser because there is some negative effect on the loser as it is mentioned before in their daily life.

\section{Ruwatan Desa Enters into Political Realm}

Ritual especially slametan and ruwatan desa in Segunung is quite related to the political realm for political actors. Through ritual or rite -it can be tablilan or other slametan that is held in Punden of Mbah Sentono before election-, political actors struggle to declare the existence of their vision and mission, but people in society rebel the political actors through ritual especially ruwatan desa. So, this turn shows how ritual enters into the political realm; in this case how runvatan desa enters into the political realm especially in a local election.

Let me back up a bit here and begin by conceptualizing ritual to see how the ritual enters into the political realm. Stating to Kertzer's point about ritual, for him "Ritual is an analytical category that helps us deal with the chaos of human experiences and put it into a coherent framework." 26 This concept of ritual is more edge from other anthropologists' view. According to him, the ritual is the tool to understand the chaos of human experiences more reasonably. It not only relates to the supernatural being but also relates to the reasonable experiences of people.

${ }^{25}$ Hestin Atas Asih, People of Segunung, Interview, , January 27, 2015

${ }^{26}$ Kertzer, Ritual, 8. 
Ritual especially ruwatan desa in the punden of mbah Sentono is very important for them. Quoting from Leach, "Ritual action is repetitive and, therefore, often redundant, but these very factors serve as important means channeling emotion, guiding cognition, an organizing social group." ${ }^{27}$ Betti who are as the elders in Segunung said that people of Segunung or other villages often do pilgrimage and ritual — such kind doing tablilan, or reciting some doa - in mbah Sentono can increase their spirituality or moreover changed their spirituality - for Leach, it is called as repetitive and, therefore, often redundant- because they can meditate and connect to the supernatural power as the media to the God. For Kertzer, he argues that "through ritual, beliefs about the universe come to be acquired, reinforced, and eventually changed." 28

It also happens in ruwatan desa. Ruwatan desa is ritual that can channel emotion through the spiritual landscape which is the punden of mbah Sentono; and it also can organize people in social relationships when they do the pilgrimage to the punden and meet while sharing together (interview with Sariman, January 28, 2015). So, this ritual including doing pilgrimage, reciting tablilan and some doa, or holding ruwatan desa in the punden of mbah Sentono is very important for most people there. Whereas as according to Kartono, there are some people or one religious organization who disagree with this ritual or rite in the punden of mbab Sentono, but they still join and participate in Kirap as one of agenda in ruwatan desa. So, I argue that this ritual can organize for the social group in society.

On the other hand, according to Kertzer, "the symbols at the heart of ritual observances are part of the tissue of myth that helps structure an understanding of the political world and the public attitude to the various political actors that populate it." 29 In Segunung, people also aware that they are advanced by some political actors and also the political actors manipulate ritual for their personal interest. So, people in society also do politic to get money from the candidate of election as political actors for ruwatan desa. They hold ruwatan desa on the big scale with big kirap and performing wayang that needs much money. Kartono said as the coordinator of the committee in ruwatan desa ritual and the polo -chief of Segunung hamlet-, the expenses of ruwatan desa with big kirap need more than 80 million rupiahs. ${ }^{30}$

\footnotetext{
27 Edmund Leach, Ritualization in Man in Relation to Conceptual and Social. Philosophical Transaction of the royal Society, Series B, 251: 403-8. 404.

${ }^{28}$ Ibid., 9.

${ }^{29}$ Ibid., 13.

${ }^{30}$ Kartono, the people of segunung, Interview, January 26, 2015.
} 
Comparing ruwatan desa before the election as this case with ruwatan desa in this year, this year ruwatan desa is held only small slametan in punden and pengajian in bale desa (Village hall) without kirap and wayang in ruwah months before Ramadhan. This situation is quite different from ruwatan desa before. According to Kartono, it is because the village does not have money for holding a big ritual.

\section{The social-political significance of ruwatan desa ritual in Segunung}

Seeing the Kertzer's case, it is similar to the case in Segunung and the important of its. He argues that there is some several importance of ritual; constructing political organizations, creating political legitimacy and solidarity, and for limiting or reducing conflict. In this turn explains the political strategy for political actor and people in society. They play political mutual connection that has some interests. So, to see the phenomenon in Segunung, this paper applies the concept from Kertzer.

\section{1) Constructing political organizations for political actors.}

Some phenomena in other places, the sacred places or punden has juru kunci - people who handle the place- who has kinship with the extraordinary quality of the people that have such kind of charisma which can, not only influence people, mobilize support in election, but also can determine people who can run or not around in the local election or pemilihan lurah. As it is explained by Weber that charismatic person has authority or power to claim and influence people. $^{31}$ In fact, in the case of Segunung, the juru kunci of the punden of Mbah Sentono did not have strong charismatic character to influence people, mobilize support in an election, and moreover determine people who can run or not around in the local election. $\mathrm{He}$ only had a specific role for holding the ruwatan desa ritual, such kind arranging the process of ruwatan desa ritual, gathering people for holding ritual or giving space for ritual.

In the 2013 local election, the candidate of local election used the juru kunci for uniting people through the rituals in the punden, not because of his charismatic, but because he had the way to handle the punden. Some political actors see the phenomena as a great situation for their personal interest in the election. Through Juru Kunci as the

${ }^{31}$ Daniel L Pals, Seven Theories of Religion (New York: Oxford University, 1996), 363. 
people who gave the place, they use ritual to tie communities or people in society to choose them in the election. As according to Kertzer, "This use of ritual to tie local communities to the center of state power also assumes urgency when new national establish." 32 In Segunung as the primary case which is miniature of the case that on Kertzer's researched, the rite which is tablilan or ruwatan desa in the punden of mbah Sentono is used by political actors to come the center of political power in the local election. This spiritual landscape for society becomes media for looking for supporters or cocok in the election as an example of building a political organization.

One of the committees in the election said that the candidates of lurah do camping seven months before the election. One of their strategies is having power and handled the punden, because punden is an important element for people in society which is already embodied in them. ${ }^{33}$

So, most of the candidates do the pilgrimage to show their image by introducing themselves and their vision-mission to society. They tried to demonstrate that they have the ability to handle the village with their visions and missions. For Kertzer, the candidates of the election do it to show their highly ritualized appearances. For him, "The metaphor of a journey guides the entire enterprise: campaign as the pilgrimage. The population is supposed to get to "know" the candidate through his highly ritualized appearances, while the candidate uses the rites to present a certain image of him and to contrast this with the image he creates of his competitors." 34

Yet, Ritual communicates not only the authority of the head of the state or organization; it is also important in making claims to positions of political importance within that state. In Segunung, as it is mentioned before, the rite especially tablilan is held before the election which is quite important for political actors to show the existences and importance of them for developing village into a better condition by declaring their vision and mission when they become lurah.

\section{2) For creating political legitimacy and solidarity.}

Ritual is already embodied in people's soul which cannot be separated in Segunung. Ritual is transmitted orally to the next generation by the previous ancestors with the old ritual form which is

\footnotetext{
32 Kertzer, Ritual, 23.

${ }^{33}$ Muslimin, the people of Sumberingin, Interview, May 2, 2015.

${ }^{34}$ Ibid., 108.
} 
still maintained. In Segunung, people in society still keep maintaining the ruwatan desa ritual as their tradition and their religious activity. It is embodied in their daily life. Ruwatan desa ritual is an old ritual form that is maintained until today. As according to Betti - one of the elders in Segunung-, the form of ritual has Pakem. Pakem means the standardization of form an element of ritual need or it can be called as a guideline the form of ritual including an element of sesajen. It can be seen that this is also the way to maintain their tradition. For him, it is already embodied in their daily life. So, from this embodied tradition, it is impossible to be separated. This occasion can be good opportunities for political actors in the election.

Some of the committees on head village election said that the candidates of election use this ritual -as their good opportunity- and keep maintaining ruwatan desa and other rites such kind tablilan, nyekar, and so on to make it into their new and hidden purposes. The new purpose is looking for the supporters in the election because by doing rite or ritual before the election, they can explore their vision and mission to people and show their political importance position for the village. This phenomenon is similar to Kertzer's research. According to him, "New political systems borrow legitimacy from the old by nurturing the old ritual forms, redirected to a new purpose." 35

On the other hand, quoting from Kertzer's statement, he pointed in his research that in rendering their political system sacred through the use of ritual, people also end up legitimizing the power held by political leaders. People in society are aware of this political purpose, so they are also constructed and do political purpose to counter the political actors' use of the ritual. Seeing the case in Segunung, people are aware and encouraged to do political mind for holding big ruwatan desa and big kirap. The committees of election ask contribution from the candidate of lurah (village head) for holding ruwatan desa because ruwatan desa need much money.

On the other hand, the ritual is used by some political actors for making a good social function in the relation of people in society. Let me quote the statement from Catherine Bell, she also quotes from Robertson Smith, Evans-Pritchard, Fortes, and Munn all appealed to this basic feature of ritual in describing its role in socialization. They are representative of the tendency, as David Kertzer puts it, to see social solidarity as a requirement of society and ritual as an indispensable element in the creation of that solidarity. Also according

${ }^{35}$ Kertzer, 108. 
to Kertzer, He argues that "One of crucial function of ritual is to produce solidarity in the absence of any commonality of beliefs." 36 Beside ritual as important landscape for people, it can strengthen solidarity of people - or in Kertzer's word is producing solidarity in the absence of any communal of beliefs-, because people in Segunung come from different backgrounds, ethnics, religions and gather in the same event, place, and without conflicting basic background of their identity. It can be good to produce solidarity and negotiation way for people after the election. Because as Kertzer said that solidarity is produced by people acting together, not people thinking together. ${ }^{37}$ On the other hand, the Mubammadiyah categorized ruwatan desa as shirk (idolatry), but the important to underline is that Mubammadiyah member do not join this ruwatan desa or some slametan as according to their belief but they participated in kirap or parade and gave financial contribution for the event because they understand the ruwatan desa ritual that is quite important for solidarity.

\section{3) For limiting or reducing conflicts.}

As it is mentioned before, Segunung can be categorized as high competition for some candidates and cocok (supporter's actors) and the impact is going on for several months. Because they use all kind of strategies to get supporters, they sometimes use money politic strategy to reach it. This phenomenon can give negative impact on the social relation of people in the village. They are divided into several groups according to their political taking up, moreover, they do not share each other like before election. The situation is quite different from the previous situation.

The lurah or the winner of head village election uses ruwatan desa as the way of negotiation for limiting and reducing the conflicts in Segunung because of head village election. By enlisting committee from a different political background and doing ritual in the same place, time, situation, it can be a good way to neutralize the conflict that happens.

As according to the Lurah - this position is taken by Sumadi Siswo Utomo-, he argues that his ruwatan desa quite help him into good condition for people in society. Moreover, it can be good media to build and take care of the village into better progression, because by getting supports, agreement and helps from people in the village, this village will be in a good situation too.

\footnotetext{
${ }^{36}$ Ibid., 66.

37 Ibid., 76.
} 
So, there is a political mutual connection between people in society and political actor through ruwatan desa ritual in the punden of Mbah Sentono. It shows the social-political significance of ruwatan desa ritual in Segunung.

\section{Conclusion}

In relation to the significance of ruwatan desa practiced in the Punden of Mbah Sentono, it needs first to explain the existence of Mbah Sentono. Historically speaking, Mbah Sentono was a man who cleared the forest for the village in Segunung. Javanese people called the act as "babat desa". People in Segunung believe that Mbah Sentono had supernatural power and protected the village from bad situations until today, although he died a long time ago. Until nowadays, the punden of Mbah Sentono is considered a sacred landscape which can increase the spirituality of people. People often come to the punden and meditate to search for spiritual meanings. So, it is embodied in people's life. Conceptually speaking, from those historical reasons, people in Segunung hold ruwatan desa ritual in the punden of Mbah Sentono every ruwah month with a set of agenda.

During the election of the head of the village in late 2013 and after the election in 2014, people in Segunung renovated the punden and held ruwatan desa ritual in a different way. They held ruwatan desa in big scale and big kirap (parade), and it was surprisingly uncommon event triggering some critical questions since I lived there and I had never seen quite big ruwatan desa ritual in Segunung. How did people hold this ritual? Where did people get much money for this big event? Is there any interest behind this event? From those questions, I have some hypotheses.

Here are my important findings from the field as a result of my research. During the 2013 election, the candidates of village head used the punden of Mbah Sentono as media of their campaign, because it is an important element for people in Segunung. So, through ritual —small ritual like tablilan and slametan - in the punden of Mbah Sentono, the candidates of lurah built and collected the political supporters and showed their importance of political position for the village by delivering their vision and mission. Kertzer called it as constructing political organizations for political leaders.

After the election, as I assumed before, there were some conflicts among people as its impact. Because of money politics, people were divided into several groups automatically based on their 
political credibility. So, through Ruwatan desa ritual in 2014 , the winner of the village used this event to reduce the conflict, strengthened solidarity, and made it as a way of reconciliation through negotiation. But, interestingly, people were aware that during the election, the leader used the event to legitimize their personal political interest. So, through ruwatan desa ritual in 2014, people tried to end up and had political interest to ask much money for holding ruwatan desa ritual in big scale, because they thought that this ritual is very important to be held in the big event.

In this paper, I have shown the social-political significance of the ritual using theoretical framework informed by Kertzer in ways that ritual constructs political organizations for political leaders, creates political legitimacy and solidarity, and limits or reduces conflicts. I confirm that theoretical framework informed by Kertzer by representing the case in Segunung as explained above.

\section{Bibliography}

Amaliyah, Eva Ida. Makna Ritual dan Bersib Desa serta Respons di Kalangan Masyarakat Desa Sekoto Kecamatan Pare Kabupaten Kediri. Gadjah Mada University: Center for Religious and Cross-cultural Studies, 2007.

Allerton, Chaterine. "Introduction: Spiritual Landscapes of Southeast Asia, 235-251". Anthropological Forum, Vol. 19, No. 3 (Nov, 2009). Routledge.

Geertz, Clifford. The Religion of Java. Chicago: The Chicago University Press, 1960.

Kertzer, David L. Ritual, Politic, and Power. London: Yale university press, 1988.

Laksana, Albertus Bagus. Muslim and Catholic Pilgrimage Practices. Burlington: Ashgate, 2014.

Leach, Edmund. Ritualization in Man in Relation to Conceptual and Social. Philosophical Transaction of the royal Society, Series B, 251: 403-8.

Moller, Andre. Ramadan in Java: The Joy and Jihad of Ritual Fasting. Sweden: Lund University, 2007.

Neuman, W. Lawrence. Social Research Method; Qualitative and Quantitative Approaches. Boston: Pearson Education, Inc, 2003.

Pals, Daniel L. Seven Theories of Religion. New York: Oxford University, 1996.

Woodward, Mark R. Java, Indonesia and Islam. New York: Springer, 2011. 


\section{Interview}

Hasan, (The Islamic leader of Segunung: people of Segunung village), record to author, interview in her house, January 25, 2015).

Hestin Atas Asih, (The people of Segunung: people of Segunung village), record to author, interview in her house, January 27, 2015.

Kartono, (The chief of Segunung Hamlet (Polo Dusun): people of Segunung village), record to author, interview, January 26, 2015

Muslimin, (The people and committee of election in Segunung: people of Segunung village), record to author, interview his house, May 2, 2015

Sariman, (nursing of Mbah Sentono's grave, Segunung), record to author interview, January 28, 2015

Sumadi Siswo Utomo, (The official leader (Lurah) of Segunung: people of Segunung village), record to author, interview his house, January 24, 2015.

Sumaiyah, (The people of Segunung: the bakul of Segunung village), record to author, interview in the street, May 2, 2015.

Suwardi, (The people of Segunung village, Segunung), recorder to author, interview in his house, February 01, 2015. 